\title{
Resensi
}

\section{Otonomi dan Pembangunan Daerah}

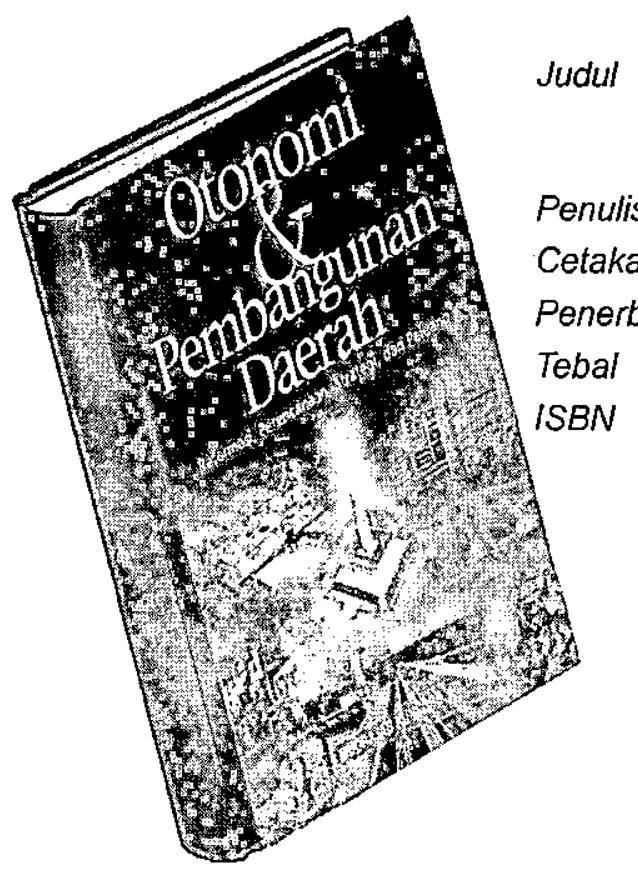

telah menimbulkan gerakan-gerakan separatisme, dan untuk mencegahnya pemerintah pusat melakukan dekrit 5 Juli 1959 yang menandai sistem administrasi pemerintahan sentralistik. Pemerintahan yang bersifat sentralistik terus berlanjut pada pemerintahan Orde Baru meskipun UU Pemerintahan Daerah telah diganti dengan UU No. 5 tahun 1974. Sistem pemerintahan sentralisasi masa Orde Baru telah menghasilkan berbagai ketimpangan dan ketidakadilan. Ketimpangan yang terjadi tidak hanya ketimpangan antardaerah saja tetapi juga ketimpangan antara desa - kota, ketimpangan antargolongan, dan juga ketimpangan antarsektor. Ketidakadilan yang terjadi juga tidak hanya ketidakadilan ekonomi, tetapi juga ketidakadilan berpolitik, bersosial, berbudaya, dan hukum. Ketimpangan, yang terjadi ditambah dengan ketidakadilan, telah menghasilkan krisis multidemensi dan konflik sosial di berbagai daerah yang masih berkepanjangan sejak tahun 1997.

Krisis multidimensi ini menimbulkan keinginan untuk melakukan enam agenda reformasi, yang meliputi amandemen UUD 
1945, penghapusan dwifungsi ABRI, otonomi daerah, penyehatan ekonomi, pemberantasan $\mathrm{KKN}$, dan penegakan hukum. Agenda reformasi, yang menjadi tanggung jawab MPR dan DPR, telah dilakukan seperti amandemen UUD 1945, penghapusan pengangkatan anggota parlemen dari TNI-Polri, Tap-tap MPR tentang penyehatan ekonomi, pemberantasan KKN, penegakan hukum, dan berbagai UU baru termasuk UU No. 22 Tahun 1999 tentang Pemerintahan Daerah dan UU No.25 Tahun 1999 tentang Perimbangan Keuangan Pemerintahan Pusat dan Daerah.

Penerapan kedua UU tentang otonomi daerah tersebut, yang dilakukan sejak tahun 2001, telah menimbulkan dampak yang menggembirakan maupun yang kurang baik. Dampak yang menggembirakan adalah masing-masing daerah berusaha dan berkompetisi untuk membangun daerahnya. Kreativitas dan strategi pembangunan daerah mulai dikembangkan dengan berbasis pada kemampuan dan kemauan masyarakat di masing-masing daerah. Pemerintahan daerah dan lembaga legislatif daerah (DPRD) menentukan sendiri misi visi dan strategi pembangunan daerah yang akan dilakukannya dalam melaksanakan limpahan urusan pemerintahan pusat dan pungutan pajak dari pemerintah pusat. Dampak yang kurang menggembirakan antara lain adalah praktik KKN di pemerintahan pusat menular ke pemerintahan daerah, fanatisme kedaerahan, melemahnya koordinasi antar daerah dan juga daerah dengan pusat dalam pembagian urusan, pelayanan publik, dan integrasi pembangunan yang berkelanjutan. Meskipun demikian, penerapan kedua UU otonomi daerah tersebut membutuhkan political will pemerintah pusat dan daerah, kesabaran menunggu proses institusi dan pemerintahan daerah bekerja, dan melakukan penelitian lebih dalam tentang implimentasi dan pengembangan pelaksanaan otonomi daerah.

Buku yang ditulis oleh Mudrajad Kuncoro ini dibagi menjadi 4 bagian dengan 17 bab, mencoba membahas implementasi otonomi daerah dan reformasi pembangunan daerah. Bagaimana pemerintah daerah melakukan perencanaan pembangunan daerah? Bagaimana strategi pembangunan, yang berbasis potensi sumber daya.di daerah dan peluang pengembangan bisnis di daerah, ditentukan? Pada bagian satu, buku ini dibagi menjadi 2 bab. Bab yang pertama menjelaskan secara singkat ide dasar desentralisasi yang merupakan pencerminan pasal 18 UUD 1945. Format sistem administrasi pemerintahan otonom dan desentralisasi kekuasaan politik dan ekonomi terus mengalami perubahan. Setelah merdeka dari penjajah Belanda, pemerintahan baru tersebut tidak dengan mudah dapat memutuskan format sistem administrasi pemerintahan daerah dan pola hubungan pemerintahan daerah dengan pusat. Pendulum sentralisasi dan desentralisasi terus berayun mengikuti konfigurasi kekuasaan saat ini. Pada tahun 1959, format pemerintahan bersifat otonomi terbatas setelah turunnya efektifitas kekuasaan pusat atas daerah dan menjamurnya gerakan separatisme. Pemerintahan, yang bersifat otonomi terbatas tersebut, berlangsung sampai tahun 1974. Pada tahun 1974, pemerintah orde baru mengeluarkan UU No. 5 Tahun 1974. Dengan UU tersebut, pemerintahan bersifat sentralisasi. Sentralisasi pemerintahan tersebut berlangsung hingga dikeluarkan UU No. 22 dan No. 25 Tahun 1999 dan juga sebagai akhir pemerintahan orde baru.

Sentralisasi pemerintahan selama orde baru tersebut tidak secara mudah berbalik 
'menjadi pemerintahan otonomi luas. Pemerintah daerah menghadapi berbagai kendala, yang antara lain: rendahnya PAD, rendahnya kualitas sumber daya manusia, tingginya dominasi kekuasaan politik dan ekonomi Pemerintah Pusat. Ketergantungan daerah terhadap Pusat tersebut menjadikan daerah tidak memiliki BUMD yang dapat diandalkan, kurusnya objek pajak yang menjadi wewenang daerah menarik pajak, dan tingginya subsidi diberikan pusat ke daerah yang membuat daerah tidak mandiri.

Pada bab 2 menjelaskan bagaimana pemerintah daerah melakukan proses perubahan struktur pemerintahan sebagaimana diatur dalam UU No. 22 Tahun 1999. Pemerintah daerah mendapatkan penyerahan wewenang Pemerintah Pusatke pemerintah daerah, pelimpahan wewenang Pemerintah Pusat ke pemerintah daerah, dan tugas perbantuan pemerintah daerah kepada Pemerintah Pusat. Penyerahan, pelimpahan, dan perbantuan tersebut tidak hanya meliputi urusan administrasi pemerintahan yang diatur dalam UU No.22 Tahun 1999, tetapi juga dana perimbangan pemerintah Pusat-Daerah dan pemungutan pajak yang dapat dilakukan oleh pemerintah daerah yang diatur dalam UU No. 25 Tahun 1999. Sampai saat diterbitkan buku ini, terdapat enam isu sentral pelaksanaan otonomi daerah, antara lain adalah masalah: urusan, pelayanan publik, lemahnya koordinasi antar sektor dan daerah, pembagian sumber pendapatan, fanatisme sempit, dan masalah ancaman disintegrasi.

Pada bagian dua, penulis menjelasan tiga hal yang terbagi dalam tiga bab, yaitu: perencanaan pembangunan daerah (bab 3), merumuskan visi dan misi (bab 4), dan contoh kasus transformasi ekonomi daerah yang berbasis tambang (bab 5). Pada bab 3 , penulis melakukan penjelasan cukup detail mengenai pokok-pokok perencanaan daerah yang sangat diperlukan. Pemerintah daerah harus melakukan proses perubahan perencanaan pembangunan daerah yang lebih otonom. Penulis membandingkan tiga pendapat mengenai tahapan pembangunan. Menurut Blakely (1989) proses perencanaan melalui enam tahapan yang berurutan, yang dimulai dari pengumpulan dan analisis data, sampai persiapan perencanaan keseluruhan dan implementasi program yang telah disusun, sedangkan menurut Bendavid-Val (1991) proses perencanaan berlasung secara simultan dan proses perencanaan pembangunan masa orde baru. Disamping perubahan proses perencanaan, pemerintah daerah juga melakukan perubahan prosedur perencanaan yang bersifat top-down menjadi bottom up. Permasalahan yang timbul adalah bagaimana mengkombinasikan antara perencanaan yang diturunkan dari Propenas (bersifat top down) dengan usulan yang muncul dari Musbangdes Tingkat Desa (bersifat botton up). Pada saat ini, kedua prosedur perencanaan tersebut bertemu di Rakorbang Tingkat Kota atau Kabupaten.

Pada bab 4, penulis mengetengahkan bagaimana visi dan misi dibangun. Setelah visi dan misi ditentukan, pemerintah daerah menentukan strategi dan program aksi yang akan dilakukan. Strategi dan program aksi pemerintah daerah tersebut tertuang dalam Renstra. Dalam buku ini, penulis memberikan beberapa contoh visi dan misi di beberapa Kabupaten dan Propinsi.

Sebagai penutup bagian dua ini, penulis memberikan kasus Kabupaten Kutai Timur. Dalam bab ini, penulis menjelaskan secara detail mulai dari profil daerah sampai menetapkan renstra yang akan dilakukannya. Kasus ini sangat berguna dan membantü pembaca mendapatkan gambaran riil penyusunan perencanaan dan 
dapat menerapkan penyusunan perencanaan untuk daerah lain.

Pada bagian tiga, penulis membahas bagaimana strategi pembangunan daerah, yang dipilih, perlu disesuaikan dengan kondisi dan permasalahan yang dihadapi daerah. Dalam bagian tiga ini, penulis memberikan kasus riil pemilihan strategi pembangunan yang dihadapi di daerah. Kasus riil yang ditulis adalah strategi menyelesaikan masalah ketimpangan pertumbuhan ekonomi antar kecamatan di Kabupaten Banyumas (bab 7); strategi penanggulangan kemiskinan (bab 8); strategi pengembangan industri (bab 9); strategi pengembangan industri pedesaan di Kalimantan Timur (bab 10); strategi pengembangan kawasan andalan di Kalimantan Selatan (bab 11); strategi pengembangan di kawasan perdagangan bebas di Batam (bab 12); dan strategi memberantas korupsi dan membangun good governance (bab 13). Penjabaran kasus strategi pembangunan daerah ini merupakan keunggulan buku ini dibandingkan buku tentang otonomi daerah yang masih terkesan normatif.

Pada bagian empat, buku ini ditutup dengan peluang pengembangan bisnis yang dapat dilakukan oleh pemerintah daerah (bab 14-16), dan polemik terhadap revisi UU No. 22/1999 dan UU No.25/1999. Pada bab 14, pembaca mendapa'kan penjelasan bagaimana peran pemerintah daerah, dalam mewujudkan obsesi peningkatan daya saing dan memasarkan agar menarik investor untuk berinvestasi di daerahnya. Bab 14 ini ditutup dengan kasus pemerintah Kabupaten Bantul mengundang investor untuk berinvestasi di sektor pariwisata.

Pada bab 15, pengembangan bisnis di daerah tidak dapat dipisahkan oleh bekerjanya kelembagaan dan tersedianya fasilitas di daerah. Kinerja masing-masing lembaga terkait akan memberikan kontribusi terhadap keberhasilan kinerja bisnis di daerah. Misalkan: untuk mengembangkan usaha kecil perlu mendapat dukungan berbagai lembaga antara lain adalah: Deperindag, Depdiknas, Depnaker, Depsos, Depkeu, Bappenas, Depkop dan PPK, Pemerintah Daerah, Bappeda, Dinas Tata Kota, Lembaga Swadaya Masyarakat, Lembaga Penelitian di Perguruan Tinggi, Asosiasi Pengusaha Kecil, dan pelaku usaha kecil. Salah lembaga tidak bekerja, maka kinerja usaha kecil tidak sebagaimana diharapkan.

Selain bekerjanya kelembagaan terkait di daerah, kinerja bisnis juga ditentukan oleh ketersedian fasilitas di daerah. Sebagai salah satu penyebab mengapa pembangunan Kawasan Timur Indonesia (KTI) tertinggal dengan pembangunan Kawasan Barat Indonesia (KBI) adalah rendah minat investor di KTI. Rendahnya minat investor tersebut disebabkan oleh mahalnya investasi di KTI dan minimnya fasilitas publik yang diperlukan daiam pengembangan bisnis dan usaha. Oleh karenanya, untuk mengejar ketertinggalan pembangunan $\mathrm{KTI}$, pemerintah pusat membentuk KAPET yang berdasarkan pada Keppres No. 120 Tahun 1993 (bab 16). KAPET ini merupakan kristalisasi ide pengembangan kawasan andalan.

Sebagai penutup bagian empat ini, penulis menutup dengan epilog mengenai polemik revisi UU No. 22 dan No. 25 Tahun 1999. Mungkin karena keterbatasan waktu akan segera cetak dan juga masih berlangsungnya polemik tersebut, penulisan bab ini terasa belum tuntas.

Buku ini memiliki kelebihan, antara lain adalah sistematika penulisan buku yang mudah diikuti dan dipahami, dan dilengkapi 
dengan berbagai data dan kasus empiris tentang masalah yang dibicarakan. Data dan kasus empiris tersebut akan mempermudah pembaca memahami dan mengaplikasikan kasus untuk daerah lain baik ditujukan untuk penelitian ataupun untuk menentukan kebijakan yang akan diambil. Buku akan bertambah lengkap bila menambahkan: (1) kasus atau bahasan tentang penyusunan alokasi mata anggaran di APBD. Penentuan alokasi mata anggaran APBD yang dilakukan oleh pemerintah daerah dan DPRD mempunyai andil dalam menentukan arah pembangunan yang dihasilkannya; (2) menuntaskan pembahasan polemik terhadap revisi UU No.22 dan No. 25 Tahun 1999. Mengapa terjadi dorongan untuk mengurangi kekuasaan pemerintah daerah tingkat dua dan peningkatan peran pemerintah daerah tingkat satu? Meskipun demikian, buku ini patut mendapat penghargaan dan layak dibaca oleh pengambil kebijakan, praktisi, kalangan akademis, dan pemerhati masalah-masalah pembangunan daerah.

Awan Setya Dewanta 